\title{
PENGARUH UKURAN PERUSAHAAN, UMUR PERUSAHAAN DAN LABA RUGI TERHADAP AUDIT DELAY Iranovia Sibarani
}

Prodi Akuntansi, Fakultas Ekonomi, Institut Manajemen Koperasi, Indonesia iranoviasibarani@gmail.com

\begin{abstract}
Abstrak
Latar belakang: Perusahaan bisa dikatakan sudah go public jika telah menerbitkan sahamnya di Bursa Efek Indonesia (BEI) yang bertujuan agar menambah dana modal perusahaan untuk kegiatan operasional.

Tujuan penelitian: Menguji hubungan ukuran perusahaan terhadap audit delay pada perusahaan yang terdaftar di BEI tahun 2016-2020, menguji hubungan umur perusahaan terhadap audit delay pada perusahaan yang terdaftar di BEI tahun 2016-2020, menguji hubungan laba rugi terhadap audit delay pada perusahaan yang terdaftar di BEI tahun 2016-2020, menguji pengaruh ukuran perusahaan,umur perusahaan dan laba rugi terhadap audit delay pada perusahaan yang terdaftar di BEI tahun 2016-2020, mengetahui gambaran audit delay pada perusahaan yang terdaftar di BEI tahun 2016-2020, jenis data yang digunakan adalah data sekunder berupa annual report.

Metode penelitian: Metode pengambilan sampel menggunakan metode purposive sampling, sedangkan metode analisis data menggunakan metode analisis deskriptif, uji asumsi klasik, uji kelayakan model dan uji hipotesis.

Hasil penelitian: Hasil penelitian ini menunjukan bahwa ada hubungan negatif ukuran perusahaan dan umur perusahaan dengan audit delay, dan adanya pengaruh laba rugi terhadap audit delay tetapi tidak signifikan.
\end{abstract}

Kesimpulan: Hasil pengujian menunjukkan bahwa ukuran perusahaan tidak memiliki hubungan positif terhadap audit delay. Hal tersebut berarti semakin besar ukuran perusahaan maka audit delay semakin sedikit. Hasil pengujian menunjukkan bahwa umur perusahaan memiliki hubungan negatif terhadap audit delay. Hal tersebut berarti semakin besar umur perusahaan maka audit delay semakin sedikit. Hasil pengujian menunjukkan bahwa laba/rugi tidak memiliki hubungan yang signifikan terhadap audit delay. Hal tersebut berarti perusahaan yang mengalami laba maka audit delay semakin rendah tetapi tidak signifikan, juga perusahaan yang mengalami rugi maka audit delay semakin besar tetapi tidak signifikan. Hasil pengujian menunjukkan bahwa ukuran perusahaan, umur perusahaan dan laba rugi bersama-sama berpengaruh terhadap audit delay. Hal tersebut berarti jika perusahaan memiliki ukuran perusahaan dan umur perusahaan yang besar, dan mendapat laba maka audit delay semakin rendah dan juga sebaliknya. Hasil pengujian menunjukkan bahwa hanya 15 perusahaan dari 199 sampel perusahaan yang mengalami audit delay pada perusahaan yang terdaftar di Bursa Efek Indonesia periode 20162020.

Kata kunci: Ukuran Perusahaan, Umur Perusahaan, Laba Rugi, Audit Delay

\begin{abstract}
Background: A company can be said to have gone public if it has issued its shares on the Indonesia Stock Exchange (IDX) which aims to increase the company's capital funds for operational activities.

Research purposes: Testing the relationship of company size to audit delay in companies listed on the IDX in 2016-2020, testing the relationship between company age and audit delay in companies listed on the IDX in 2016-2020, testing the relationship between profit and loss on audit delay in companies listed on the IDX in 2016-2020, examining the effect of company size, company age and profit and loss on audit delay in companies listed on the IDX in 2016-2020, knowing the description of audit delay in companies listed on the IDX in 2016-2020, the type of data used is secondary data. in the form of an annual report.

Research methods: The sampling method used purposive sampling method, while the data analysis method used descriptive analysis methods, classical assumption tests, model feasibility tests and hypothesis testing.

Research results: The results of this study indicate that there is a negative relationship between firm size and firm age with audit delay, and the effect of profit and loss on audit delay but not
\end{abstract}


significant.

Conclusion: The test results show that firm size does not have a positive relationship to audit delay. This means that the larger the size of the company, the less audit delay. The test results show that the age of the company has a negative relationship to audit delay. This means that the greater the age of the company, the less audit delay. The test results show that profit/loss has no significant relationship to audit delay. This means that companies that experience profits have a lower but not significant audit delay, and companies that experience losses have a larger but not significant audit delay. The test results show that firm size, firm age and profit and loss together have an effect on audit delay. This means that if the company has a large company size and age, and gets a profit, the audit delay will be lower and vice versa. The test results show that only 15 companies out of 199 sample companies experienced audit delay in companies listed on the Indonesia Stock Exchange for the 2016-2020 period.

Keywords: Company Size, Company Age, Profit and Loss, Audit Delay

Diterima: 26-11-2021; Direvisi: 29-11-2021; Disetujui: 14-01-2022

\section{PENDAHULUAN}

Semakin bertambahnya jumlah perusahaan di Indonesia yang go public membuktikan bahwa dunia bisnis di Negara tersebut mengalami perkembangan. Hal ini dibuktikan pada tahun 2016 sebanyak 537 perusahaan tercatat di Bursa Efek Indonesia (BEI), pada tahun 2017 sebanyak 566 perusahaan, pada tahun 2018 sebanyak 619, pada tahun 2019 sebanyak 668 ,pada tahun 2020 sebanyak 713, dan pada tahun 2021 sebanyak 722 perusahaan Ini berarti terjadi kenaikan sebesar 34,45\% dari tahun 2014 sampai tahun 2021 (www.idx.co.id).

Fenomena yang terjadi pada tahun 2020 sebanyak 30 emiten dikenai denda sebesar Rp 150 juta oleh Bursa Efek Indonesia (BEI) karena telat menyampaikan laporan keuangan pertama tahun 2020. Dalam pengumuman BEI yang dikutip dari keterbukaan informasi BEI tercatat ada 26 perusahaan yang belum membuat laporan keuangan kuartal III-2020. Sebanyak 21 perusahaan tercatat belum menyampaikan laporan keuangan interin yang tidak diaudit dan tidak ditelaah secara terbatas oleh akuntan publik dan/atau belum memenuhi kewajiban pembayaran denda hingga tanggal 27 Oktober 2020. Sementara 1 perusahaan tercatat belum menyampaikan laporan keuangan yang tidak ditelaah secara terbatas dan yang tidak diaudit oleh akuntan publik dan/atau belum memenuhi kewajiban pembayaran denda hingga tanggal 27 Oktober 2020. (idxchannel.okezone.com)

Fenomena yang terjadi pada tahun 2019 dimana masih ada 107 emiten belum menyampaikan laporan keuangan semester I-2019, BEI mencatat dari 737 perusahaan baru 578 yang menyampaikan laporan keuangan semsester I-2019 yang artinya baru $78,4 \%$ dari total emiten yang melaporakan keuangan semester I-2019 yang tepat waktu. Indeks sector perdagangan, jasa dan investasi menjadi salah satu indeks sektotal yang memiliki kinerja kurang prima.

Berdasarkan latar belakang diatas, maka penulis ingin meneliti lebih lanjut mengenai hubungan antara variabel independen yaitu ukuran perusahaan, umur perusahaan, dan laba rugi. Objek dalam penelitian ini adalah perusahaan-perusahaan dari beberapa penelitian yang telah disebutkan diatas, terdapat ketidakkonsistenan hasil penelitian terkait dengan audit delay selaku variabel dependen untuk itu peneliti termotivasi menguji kembali variabel-variabel tersebut dan menganalisis kembali hubungan ketiga variabel independent diatas terhadap audit delay.

Menguji hubungan ukuran perusahaan terhadap audit delay pada perusahaan yang terdaftar di BEI tahun 2016-2020, menguji hubungan umur perusahaan terhadap audit delay pada perusahaan yang terdaftar di BEI tahun 2016-2020, menguji hubungan laba 
rugi terhadap audit delay pada perusahaan yang terdaftar di BEI tahun 2016-2020, menguji pengaruh ukuran perusahaan,umur perusahaan dan laba rugi terhadap audit delay pada perusahaan yang terdaftar di BEI tahun 2016-2020, mengetahui gambaran audit delay pada perusahaan yang terdaftar di BEI tahun 2016-2020, jenis data yang digunakan adalah data sekunder berupa annual report.

\section{METODE PENELITIAN}

Metode sampling yang dipergunakan pada penelitian ini ialah metode pengambilan sampel secara acak (purposive random sampling). Metode pengambilan sampel secara acak adalah metode pengumpulan sampling yang disesuaikan sesuai karakter tertentu yang telah ditetapkan sebelumnya untuk dijadikan sampel lebih representatif.

\section{HASIL DAN PEMBAHASAN}

\section{Analisis Statistik Deskriptif}

Tabel 1. Hasil Uji Statistik Deskriptif

\begin{tabular}{lrrrrr}
\hline \multicolumn{7}{c}{ Descriptive Statistics } \\
\hline Ukuran Perusahaan & Minimum & Maximum & Mean & Std. Deviation \\
Umur Perusahaan & 995 & 23.08 & 34.95 & 29.1928 & 1.83201 \\
Laba Rugi & 995 & 2 & 107 & 38.91 & 15.430 \\
Audit Delay & 995 & 0 & 1 & .82 & .383 \\
Valid N (listwise) & 995 & 12 & 199 & 74.05 & 21.389 \\
\hline
\end{tabular}

Sumber : Data diolah, 2021.

Dari hasil analisis deskriptif pada tabel diatas, maka kesimpulan yang dapat diambil adalah sebagai berikut :

1 Nilai minimum ukuran perusahaan adalah sebesar 23,08 yang diperoleh PT Jaya Real Property Tbk sedangkan nilai maksimum ukuran perusahaan sebesar 34,95 yang diperoleh PT Bank Rakyat Indonesia (Persero) Tbk. Nilai rata-rata ukuran perusahaan adalah sebesar 29,1928 dengan nilai standar deviasi sebesar 1,83201.

2 Nilai minimum umur perusahaan adalah sebesar 2 tahun yang diperoleh PT Waskita Beton Precast Tbk sedangkan nilai maksimum umur perusahaan sebesar 107 tahun yang diperoleh PT Bank Qnb Indonesia Tbk. Nilai rata-rata umur perusahaan adalah sebesar 38,91 dengan nilai standar deviasi sebesar 15,430.

3 Nilai minimum laba rugi adalah sebesar 0,00 sedangkan nilai maksimum laba rugi adalah sebesar 1,00. Nilai rata-rata variabel laba rugi pada perusahaan di Bursa Efek Indonesia tahun 2016-2020 adalah sebesar 0,82 dengan nilai standar deviasi sebesar 0,383 .

4 Nilai minimum audit delay adalah sebesar 12 hari yang diperoleh PT Argha Karya Prima Ind. Tbk tahun 2016 yang merupakan perusahaan dengan audit delay yang paling rendah diantara perusahaan sampel sedangkan nilai maksimum audit delay adalah sebesar 199 hari yang diperoleh PT Sunson Textile Manufacture Tbk tahun 2017 yang merupakan perusahaan dengan audit delay yang paling tinggi diantara perusahaan sampel. Nilai rata-rata audit delay tahun 2016-2020 adalah sebesar 74,05 atau 74 hari. Nilai standar deviasi sebesar 21,389 . 


\section{Uji Asumsi Klasik}

\subsection{Uji Normalitas}

Tabel 1. Hasil Uji Normalitas

One-Sample Kolmogorov-Smirnov Test

\begin{tabular}{llr} 
& & $\begin{array}{c}\text { Unstandardized } \\
\text { Residual }\end{array}$ \\
\hline $\mathrm{N}$ & & 995 \\
Normal Parameters & & \\
& Mean & .0000000 \\
Most Extreme Differences & Std. Deviation & 19.59188448 \\
& Absolute & .042 \\
Kolmogorov-Smirnov Z & Positive & .042 \\
Asymp. Sig. (2-tailed) & Negative & -.025 \\
\hline Sumber : Data diolah 2021 & & 1.324 \\
& & .060 \\
\hline
\end{tabular}

Sumber : Data diolah, 2021

Berdasarkan hasil uji Kolmogrov Smirnov diatas, menunjukkan bahwa taraf signifikan adalah sebesar 0,060 yang berada diatas 0,05. Dengan demikian dapat disimpulkan bahwa data yang digunakan dalam penelitian ini terdistribusi secara normal . 2.2 Uji Heteroskedastisitas

Tabel 2. Hasil Uji Heteroskedastisitas.

Coefficients $^{a}$

Model

$$
\text { (Constant) }
$$

Ukuran Perusahaan
$\mathrm{T}$

Sig.

\section{5}


Hasil pada tabel diatas menunjukkan seluruh variabel independen memiliki nilai Tolerance $\geq 0,10$ dan nilai VIF $\leq 10$. Sehingga kesimpulannya adalah semua variabel bebas dalam penelitian ini tidak multikolineritas.

\subsection{Uji Autokorelasi}

Tabel 3. Hasil Uji Autokorelasi

\begin{tabular}{|c|c|c|c|c|c|}
\hline \multicolumn{6}{|c|}{ Model Summary } \\
\hline Model & $R$ & R Square & $\begin{array}{l}\text { Adjusted } R \\
\text { Square }\end{array}$ & $\begin{array}{l}\text { Std. Error of the } \\
\text { Estimate }\end{array}$ & Durbin-Watson \\
\hline 1 & $.401^{\mathrm{a}}$ & .161 & .458 & 19.622 & 1.990 \\
\hline
\end{tabular}

Sumber : Data diolah, 2021.

Berdasarkan hasil uji Durbin-Watson pada tabel diatas dapat dilihat bahwa hasil uji autokorelasi nilai 1,989 dengan jumlah analisis (n) sebanyak 199 dan jumlah variabel bebas (k) adalah 3 sehingga nilai dU adalah 1,7986. Hal ini menunjukkan bahwa data tersebut bebas dari autokorelasi dikarenakan nilai dU sebesar 1,7986 lebih kecil dari DW sebesar 1,989 dan nilai DW lebih kecil dari 4-dU (4-1,7986) sebesar 2,2014 atau dapat dibuat persamaan seperti $1,7986<1,989<2,2014$.

\section{Uji Kelayakan Model (Analisis Regresi Berganda)}

Tabel 6. Hasil Uji Regresi Linear Berganda

\section{Coefficients $^{a}$}

\begin{tabular}{|c|c|c|c|}
\hline \multirow{2}{*}{ Model } & & \multicolumn{2}{|c|}{ Unstandardized Coefficients } \\
\hline & & $\mathrm{B}$ & Std. Error \\
\hline & (Constant) & 197.369 & 10.098 \\
\hline & Ukuran Perusahaan & -3.935 & 0.365 \\
\hline & 1 & & \\
\hline & Umur Perusahaan & -0.088 & 0.042 \\
\hline & Laba Rugi & -6.114 & 1.669 \\
\hline
\end{tabular}

Sumber : Data diolah, 2021

Dari hasil pengujian regresi linear berganda diatas, dapat diperoleh persamaan regresi linear berganda sebagai berikut :

$\mathrm{Y}=197,369-3,935 \mathrm{X} 1-0,088 \mathrm{X} 2-6,114 \mathrm{X} 3$

Dari hasil model persamaan regresi diatas, maka kesimpulan yang dapat diambil adalah sebagai berikut :

1 Nilai konstanta sebesar 197,369 menunjukkan bahwa apabila variabel independent bernilai 0, maka besarnya nilai audit delay akan sebesar 197,369.

2 Nilai koefisien regresi variabel ukuran perusahaan adalah sebesar $-3,935$. Hal ini dapat diartikan bahwa apabila ukuran perusahaan meningkat sebesar satu satuan, maka lamanya audit delay akan bertambah sebesar -3,935 dengan asumsi semua variabel lain tetap.

3 Nilai koefisien regresi variabel umur perusahaan adalah sebesar $-0,088$. Hal ini dapat diartikan bahwa apabila umur perusahaan meningkat sebesar satu satuan, 
maka lamanya audit delay akan bertambah sebesar -0,088 dengan asumsi semua variabel lain tetap.

4 Nilai koefisien regresi variabel laba rugi adalah sebesar -6,114. Hal ini dapat diartikan bahwa apabila laba rugi perusahaan meningkat sebesar satu satuan, maka lamanya audit delay akan bertambah sebesar -6,114 dengan asumsi semua variabel lain tetap.

\section{Uji Hipotesis}

\subsection{Uji Koefisien Determinasi $\left(\mathbf{R}^{2}\right)$}

Tabel 7. Hasil Uji Koefisien Determinasi $\left(\mathrm{R}^{2}\right)$.

\begin{tabular}{|c|c|c|c|c|c|}
\hline \multicolumn{6}{|c|}{ Model Summary $^{\mathrm{b}}$} \\
\hline Model & $R$ & $R$ Square & Adjusted R Square & $\begin{array}{l}\text { Std. Error of the } \\
\text { Estimate }\end{array}$ & Durbin-Watson \\
\hline 1 & $.401^{\mathrm{a}}$ & .161 & .458 & 19.622 & 1.99 \\
\hline
\end{tabular}

Sumber : Data diolah, 2021

Berdasarkan tabel model semuanya diatas diperoleh bahwa nilai koefisien korelasi berganda $\mathrm{R}$ sebesar 0,401. Ini menunjukkan bahwa variabel ukuran perusahaan, umur perusahaan dan laba rugi terhadap audit delay mempunyai hubungan sedang. Pada tabel diatas dapat diketahui bahwa nilai koefisien determinasi yang sudah disesuaikan (ajudsted R square) adalah 0,458. Berdasarkan teori Ghozali (2012), hal ini berarti 45,8\% variasi dari audit delay mampu dijelaskan oleh ukuran perusahaan, umur perusahaan dan laba rugi. Sedangkan sisanya $(100 \%-45,8 \%=54,2 \%)$, dipengaruhi oleh variabel lain yang tidak dianalisis dalam penelitian ini.

\subsection{Uji Statistik F}

Tabel 8. Hasil Uji Statistik F.

\begin{tabular}{llrrrrr}
\multicolumn{7}{c}{ ANOVA $^{\mathbf{b}}$} \\
Model & & Sum of Squares & Df & Mean Square & $F$ & Sig. \\
1 & Regression & 73224.799 & 3 & 24408.266 & 2.697 & $.048^{\mathbf{a}}$ \\
& Residual & 381538.886 & 991 & 385.004 & & \\
& Total & 454763.684 & 994 & & & \\
\hline
\end{tabular}

Sumber: Data diolah

Uji Statistik $F$ menunjukkan $F_{\text {hitung }} 2,697>F_{\text {tabel }}$ sebesar 2,65 dengan angka signifikan sebesar $0,048<0,05$. Sehingga dapat disimpulkan bahwa pengujian simultan menunjukan ukuran perusahaan, umur perusahaan dan laba rugi dalam model persamaan tersebut secara bersama-sama memiliki hubungan terhadap audit delay pada perusahaan yang terdaftar di BEI periode 2016-2020. 
Vol. 13, No. 1, pp. 29-37, Januari 2022

\subsection{Uji Statistik t}

Tabel 9. Hasil Uji Statistik t.

Coefficients $^{\mathrm{a}}$

\begin{tabular}{|c|c|c|c|c|c|c|}
\hline & \multirow[t]{2}{*}{ Model } & \multicolumn{2}{|c|}{$\begin{array}{c}\text { Unstandardized } \\
\text { Coefficients }\end{array}$} & \multirow{2}{*}{$\begin{array}{c}\text { Standardized } \\
\text { Coefficients }\end{array}$} & \multirow[t]{2}{*}{$\mathrm{t}$} & \multirow[t]{2}{*}{ Sig. } \\
\hline & & $B$ & Std. Error & & & \\
\hline & $($ Constant $)$ & 197.369 & 10.098 & & 19.545 & 0.004 \\
\hline \multirow{3}{*}{1} & $\begin{array}{l}\text { Ukuran } \\
\text { Perusahaan }\end{array}$ & -3.935 & 0.365 & -0.337 & -10.776 & 0.222 \\
\hline & $\begin{array}{l}\text { Umur } \\
\text { Perusahaan }\end{array}$ & -0.088 & 0.042 & -0.064 & -2.079 & 0.008 \\
\hline & Laba Rugi & -6.114 & 1.669 & -0.11 & -3.664 & 0.091 \\
\hline
\end{tabular}

Sumber : Data diolah

Pengujian ini dilakukan untuk melihat hubungan dari masing-masing variabel independen secara parsial terhadap variabel dependen dengan tingkat signifikansi $(\alpha)=$ 0,05 atau kepercayaan $95 \%$. Nilai $t_{\text {tabel }}$ dari penelitian ini adalah 1,971. Berdasarkan hasil output diatas, pengujian hipotesis dalam penelitian ini dapat dijabarkan sebagai berikut :

a) Pengujian hipotesis variabel ukuran perusahaan.

Hipotesis pertama dalam penelitian ini adalah ukuran perusahaan memiliki hubungan positif terhadap audit delay. Dari tabel 4.9 diketahui bahwa koefisien $\beta$ X1 bernilai negatif sebesar $-3,935$ nilai $t_{\text {hitung }}$ sebesar $-10,776>$ nilai $\mathrm{t}_{\text {tabel }}$ sebesar 1,971 dan nilai probabilitas signifikan 0,222 >0,05. Hal ini berarti bahwa ukuran perusahaan memiliki hubungan negatif terhadap audit delay, sehingga dapat disimpulkan hipotesis 1 ditolak.

b) Pengujian hipotesis variabel umur perusahaan

Hipotesis kedua dalam penelitian ini adalah umur perusahaan memiliki hubungan negatif terhadap audit delay. Dari tabel 4.9 diketahui bahwa koefisien $\beta$ X2 bernilai negatif sebesar $-0,088$, nilai $t_{\text {hitung }}$ sebesar $-2,079>$ nilai $t_{\text {tabel }}$ sebesar 1,971 dan nilai probabilitas $0,008<0,05$. Hal ini berarti bahwa umur perusahaan memiliki hubungan negatif terhadap audit delay, sehingga dapat disimpulkan hipotesis 2 diterima.

c) Pengujian hipotesis variabel laba rugi

Hipotesis ketiga dalam penelitian ini adalah laba rugi memiliki hubungan signifikan terhadap audit delay. Dari tabel 4.9 diketahui bahwa koefisien $\beta$ X3 bernilai negatif sebesar $-6,114$ nilai $t_{\text {hitung }}$ sebesar $-3,664>$ nilai $t_{\text {tabel }}$ sebesar 1,971 dan nilai probabilitas $0,091>0,05$. Hal ini berarti bahwa laba rugi tidak memiliki hubungan signifikan terhadap audit delay, sehingga dapat disimpulkan hipotesis 3 ditolak.

\section{KESIMPULAN}

Berdasarkan hasil temuan penelitian dan pengujian hipotesis yang telah dilakukan dapat disimpulkan bahwa hasil pengujian menunjukkan bahwa ukuran perusahaan tidak memiliki hubungan positif terhadap audit delay. Hal tersebut berarti semakin besar ukuran perusahaan maka audit delay semakin sedikit. Hasil pengujian menunjukkan bahwa umur perusahaan memiliki hubungan negatif terhadap audit delay. Hal tersebut berarti semakin besar umur perusahaan maka audit delay semakin sedikit. Hasil pengujian 
menunjukkan bahwa laba/rugi tidak memiliki hubungan yang signifikan terhadap audit delay. Hal tersebut berarti perusahaan yang mengalami laba maka audit delay semakin rendah tetapi tidak signifikan, juga perusahaan yang mengalami rugi maka audit delay semakin besar tetapi tidak signifikan. Hasil pengujian menunjukkan bahwa ukuran perusahaan, umur perusahaan dan laba rugi bersama-sama berpengaruh terhadap audit delay. Hal tersebut berarti jika perusahaan memiliki ukuran perusahaan dan umur perusahaan yang besar, dan mendapat laba maka audit delay semakin rendah dan juga sebaliknya. Hasil pengujian menunjukkan bahwa hanya 15 perusahaan dari 199 sampel perusahaan yang mengalami audit delay pada perusahaan yang terdaftar di Bursa Efek Indonesia periode 2016-2020.

\section{BIBLIOGRAFI}

Airin, M. W. (2020). Pengaruh Idependensi, Kompetensi, Pengalaman Kerja, Dan Ukuran KAP Terhadap Audit Delay Yang Dimediasi Oleh Kualitas Audit. JRAMB, Prodi Akuntansi, Fakultas Ekonomi, UMB Yogyakarta Volume 6 No.1, 23-25.

Alther Gabriel Liwe, H. M. (2018). Analisi Faktor-Faktor Yang Mempengaruhi Audit Delay. Jurnal Riset Akuntnansi Going Concern 13(2), 99-107.

Amani, F. A. (2016). Pengaruh Ukuran Perusahaan,Profitabilitas, Opini Audit, Dan Umur Perusahaan Terhadap Audit Delay. Jurnal Nominal, Volume V Nomor 1, 135147.

Dina Puspita Sari, E. M. (2019). Faktor - Faktor Yang Mempengaruhi Audit Delay. Jurnal Eksplorasi Akuntansi, Vol. 1, No 2, Seri B, Mei 2019, Hal 646-665.

I Putu Yoga Darmawan, N. L. (2017). Pengaruh Ukuran Perusahaan, Kompleksitas Operasi Perusahaan Dan Komite Audit Pada Audit Delay. E-Jurnal Akuntansi Universitas Udayana Vol.12.1, 254-277.

Laksito, A. I. (2015). Analisis Faktor-Faktor Yang Mempengaruhi Audit Delay. Diponegoro Journal Of Accounting Volume 4, Nomor 3, 1-10.

Ni Made Shinta Widhiasari, I. K. (2016). Pengaruh Umur Perusahaan, Ukuran Perusahaan, Reputasi Auditor, Dan Pergantian Auditor Terhadap Audit Report Lag. E-Jurnal Akuntansi Universitas Udayana Vol.15.1, 200-223.

Novi Sonia, L. S. (2019). Analisis Pengaruh Ukuran Perusahaan, Laba/Rugi Perusahaan, Ukuran KAP, Solvabilitas, Dan Opini Audit Terhadap Audit Delay. Jurnal Riset Mahasiswa Akuntansi Volume 7, No 2, 1-5.

Permatasari, I. (2018). Pengaruh Independensi Dan Kompetensi Auditor Terhadap Kualitas Audit Internal. Jrurnal Akuntansi, Audit Dan Sistem Informasi Akuntansi (Jasa) Vol.2, No.3, 15-23.

Rizki Sakti Kornelius Butarbutar, P. B. (2017). Analisis Faktor-Faktor Yang Berpengaruh Terhadap Audit Report Lag. Diponegoro Journal of Accounting Volume 6, Nomor 3, 1-10.

Rosyada, A. D. (2019). Pengaruh Kompetensi Dan Independensi Auditor Terhadap Kualitas Audit Kantor Akuntan Publik Di Makassar. Jurna Akuntansi Netral, Akuntabe, Objektif Volume 2/Nomor 1, 218.

Saragih, M. R. (2018). Pengaruh Ukuran Perusahaan, Solvabilitas Dan Komite Audit Terhadap Audit Delay. Jurnal Akuntansi Berkelanjutan Indonesia Vol.1, No 3, 353-356.

Sisilia Novi Ratnasari, Y. (2017). Pengaruh Ukuran Perusahaan, Ukuran KAP Dan Auditor Internal Terhadap Audit Delay. Junal Akuntansi Vol.5 No 2. 
Suryono, T. R. (2016). Pengaruh Independensi Auditor, Etika Auditor, Dan Pengalaman Auditor Terhadap Kualitas Audit. Jurnal Ilmu dan Riset Akuntansi Volume 5, Nomor 4, 2-4.

Syamsul Bahri, K. H. (2018). Pengaruh Ukuran Perusahaan,Umur Perusahaan, Profitabilitas, Solvabilitas Dan Ukuran Kantor Akuntan Publik Terhadap Audit Delay. Conference on Innovation and Application of Science and Technology, 178-180.

Syofyan, Y. Y. (2017). Analisis Faktor-Faktor Yang Mempengaruhi Audit Delay : Studi Empiris Pada Perusahaan Manufaktur Yang Terdaftar Di BEI Tahun 2011-2015 . Jurnal WRA, Vol 5, No 2, , 1093-1098.

Tjhoa, C. d. (2016). Pengaruh Ukuran Perusahaan, Laba Rugi Operasi, Solvabilitas, Umur Perusahaan, Klasifikasi Industri , Dan Ukuran KAP Terhadap Audit Delay. Ultima Accounting Vol.8 No.2, 66-69.

Wirakusuma, S. A. (2013). Pengaruh Profitabiltas, Leverage, Kompleksitas, Operasi ,Reputasi KAP dan Komite Audit Pada Audit Delay. E-Jurnal Akuntansi Universitas Udayana 5.2, 252-256.

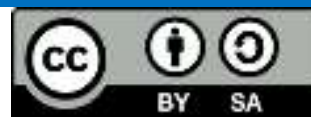

This work is licensed under a Creative Commons Attribution-ShareAlike 4.0 International License 